\title{
Research on Influencing Factors of Market -- Seeking Economic Openness under the Belt and Road
}

\author{
Zaiyang Liu \\ School of Economics and Management, Beijing Jiaotong University, Beijing 100044 China. \\ 15711013@bjtu.edu.cn
}

\begin{abstract}
This article subdivides the market-seeking Economic Openness (EO) into the marketoriented investment and trade-seeking investment and analyses the problems facing the market seeking foreign direct investment under the Belt and Road (B\&R). We conducted an empirical test on the chosen data of China's OFDI, China's import and export with countries along the route, geographical distance between China and countries along the route, National GDP, Exchange rate (direct quotation method), Economic openness, Internet popularity, Population of countries along the route based on the Trade Gravity Model of OFDI. The purpose is to explore the main factors affecting market -seeking EO under B\&R and put forward some countermeasures and suggestions on how to optimize the structure of China's EO and to improve investment efficiency.
\end{abstract}

Keywords: The belt and road (b\&r), the trade gravity model; market seeking, influencing factors, economic openness (EO).

\section{Introduction}

In recent years, with the introduction of policies and strategies related to the "Belt and Road Initiative", a growing number of Chinese enterprises have gradually begun to go global, accompanied with great development momentum and expanding scale of investment. From the current development situation, China will enjoy more space for the development of economic opening-up in the future and is gradually entering a new era of leading the global economic and trade pattern. However, compared with other developed countries, China is still in a disadvantaged position in terms of the institutional system, enterprises themselves and international investment environment. In order to explore the factors affecting the investment of Chinese enterprises in the international market environment, this paper adopts the principal component analysis to establish an index model for evaluating the trade between China and various countries, then brings relevant data on commercial trade between China and other countries in recent years into the formula for empirical test, and finally puts forward suggestions for optimizing China's economic opening-up based on the results of data analysis.

\section{Literature Review}

Zhang (2016) constructed the model by means of the principal component analysis of the average, used SPSS software to perform principal component analysis on the collected data to maximize the variance rotation, and finally obtained the scores of principle factors and the equation reflecting the contribution rate of each principal factor [1]. The "Belt and Road Initiative" has been defined as a new regional cooperation mechanism based on interconnection, which revolved around transportation channels, featured diversified cooperation mechanism, and aimed to build a community of destiny (Li, 2014) [2]. Some authors believed that against the backdrop of the economic "New Normal", the "Belt and Road Initiative" played a significant role in dealing with the difficult of growth for China's trade and even global trade as a whole (Shen \& Xiao, 2014) [3]. It has been thought that the "Belt and Road Initiative" would help promote sustained and rapid economic growth in China and other Asian countries along the route ( $\mathrm{Lu} \& \mathrm{Li}, 2015)$ [4]. Although domestic scholars have carried out profound analyses of the main factors affecting foreign direct investment, research on the main factors impacting China's economic opening-up is yet to be deepened. Since cooperation among nations is highly emphasized in strategies of the "Belt and Road Initiative", it is naturally inseparable from the 
opening up of the economy. Therefore, it is necessary to study the main factors affecting economic opening-up.

\section{The Problems Facing the EO under B\&R}

\subsection{The Problems Facing the EO disparity between China and the World}

In recent years, economic exchanges between China and the world have continued to increase, so has China's trade openness. Although there were some ups and downs around 2008, the overall trend has been steadily rising. At present, China is the world's largest trading nation and the developing country that absorbs the most foreign investment. However, China's economic openness is far below the world average, being one of the countries with the lowest economic openness in the world. What's more, China's import and export trade has barely increased its contribution rate to GDP while the latter keeps growing. All this has illustrated that China's economic openness still has a lot of room for development, and it needs promoting by the enhancement of foreign trade and investment. In addition, due to the complexity of the international economic market environment, it is worthwhile to consider how China can take appropriate measures on the issue of economic opening-up when confronted with the grave economic situation. For instance, both the Asian Crisis in 1997and the global financial crisis in 2008 exerted negative impact on China's exports and imports, bringing economic openness down to a low point [5]. Although China has overcome various difficulties and finally kept China's economic openness stable, it will meet such a crisis in the future again. Therefore, it pays to ponder on how China can still keep its economic situation well when encountering crisis.

\subsection{The Problems Facing the EO Disparity between East and West}

At present, in addition to bellowing the world average, China's economic openness varies greatly between the east and west areas due to imbalanced economic development, with the economic openness of the eastern region being far greater than that of the western region. Although the economic development gap between eastern and western regions has kept narrowing due to the implementation of the "Central Rise" plan, the "Western Development" plan, and the "Belt and Road Initiative" in recent years, there is still a large gap in economic openness on the whole. According to the 2015 China Urban and Regional Opening Index Research Report released by the National Development and Reform Commission in 2015, it can be seen that the economic openness of coastal areas is far ahead of other regions [6]. Therefore, if China wants to promote economic development so as to improve its economic openness, it must pay attention to balancing economic development in the central and western regions.

\section{Empirical Research Process}

\subsection{Theoretical Model}

Principal Component Analysis Model (PCAM) is an important analytical method in the field of statistics. It was first proposed by scholar Karl Pearson, and later improved and promoted by scholar H. Hotlin. In the beginning, PCAM was mainly applied to data analysis of non-random variables. At present, however, it has found wide application in many research fields including data analysis of random variables, covering a wide range of fields such as economics, management, and geoscience. Its mathematical expression is as follows:

$$
\left\{\begin{array}{c}
F 1=A 11 Z x 1+A 21 Z x 2+\ldots+A j 1 Z x j \\
F 2=A 12 Z x 1+A 22 Z x 2+\ldots+A j 2 Z x j \\
F M=A 1 n Z x 1+A 2 n Z x 2+\ldots+A j n Z x j
\end{array}\right.
$$

Among them, A1i, A2i ... Aji $(\mathrm{i}=1,2, \ldots \mathrm{m})$ represent the eigenvectors corresponding to the eigenvalues of the variable $\mathrm{X}$ covariance matrix, and $\mathrm{Zx} 1, \mathrm{Zx} 2, \ldots \mathrm{Zxj}$ represent the values of the 
original variables after normalization. Original variables are normalized because the raw data index units are not uniform, which will produce a biased influence on the statistical analysis results. Therefore, normalization processing is necessary to eliminate the dimensional factors, which makes the analysis results more accurate. Following this idea, this paper conducts normalization on the original variables in the subsequent empirical process. Principal component analysis mainly adopts the idea of variable dimension reduction to "reconstruct" multiple complex variables or combinations of indicators which involve correlativity so as to form new combinations that are independent of each other and contain fewer variables or indicators. These new combinations replace the original ones to study and solve practical problems, comprehensively reflecting the information of research objects contained in the original combinations. Specifically, the research steps of principal component analysis are as follows: first is to construct the indicator system and normalize raw data; second is to conduct correlation analysis and multi-collinearity test of variables; third is to analyze the contribution rate of variance and determine the number of principal components; fourth is to determine the linear combination expression of principal components; and fifth is to analyze the comprehensive evaluation index of principal components.

The regression analysis model is a statistical analysis method used to determine the quantitative relationship between two or more variables, which is widely applied. According to the number of variables involved, the regression analysis is divided into univariate regression and multiple regression analyses. According to the number of dependent variables, it can be divided into simple regression and multiple regression analyses. According to the type of relationship between independent variables and dependent variables, it can be divided into linear regression analysis and nonlinear regression analyses.

This paper conducts principal component analysis and multiple linear regression analysis of the factors affecting the degree of national economic openness by use of SPSS software. The specific linear regression model is as follows:

$$
\mathrm{EO}=\lambda 0+\lambda 1 * \mathrm{OFDI}+\lambda 2 * \mathrm{IE}+\lambda 3 * \mathrm{DIS}+\lambda 4 * \mathrm{GNDP}+\lambda 5 * \mathrm{ER}+\lambda 6 * \mathrm{IP}+\lambda 7 * \mathrm{POP}
$$

\subsection{Index Selection and Calculation}

This paper refers to the latest edition of the Investment Facilitation Action Plan (IFAP), the Trade Facilitation Action Plan (TFAP), the Doing Business Report (DBR), the Bilateral Investment Agreements (BITs), the World Investment Report (WIR), and the Global Trade Facilitation Report (GTF). It selects the following indicators for research: OFDI indicates the amount of foreign investment of each country; IE indicates the proportion of food in import and export of China and countries along the Belt and Road; DIS represents the geographical distance between China and other countries; NGDP represents the annual GDP of each country; ER stands for the exchange rate between China's RMB and countries' currencies; EO indicates the economic openness of each country; IP indicates the Internet penetration rate of each country; and POP indicates the total population of each country. The sources of each indicator are shown in Table 1:

Table 1. Index selection and calculation

\begin{tabular}{|c|c|}
\hline Index & Data Sources \\
\hline Economic openness (EO) & UN Comtrade \\
\hline Outward Foreign Direct Investment(OFDI) & $\begin{array}{c}\text { National Bureau of Statistics of the People's Republic of } \\
\text { China / Belt And Road Portal }\end{array}$ \\
\hline $\begin{array}{c}\text { China's import and export with countries along } \\
\text { the route (IE) }\end{array}$ & $\begin{array}{c}\text { National Bureau of Statistics of the People's Republic of } \\
\text { China }\end{array}$ \\
\hline $\begin{array}{c}\text { Geographical distance between China and } \\
\text { countries along the route(DIS) }\end{array}$ & CEPII \\
\hline National GDP (NGDP) & World Bank Development Indicators \\
\hline Exchange rate (direct quotation method) (ER) & OANDA \\
\hline Internet popularity (IP) & Belt And Road Portal \\
\hline Population of countries along the route (POP) & World Bank Development Indicators \\
\hline
\end{tabular}




\subsection{The Process of Empirical Analysis}

\subsubsection{Data Sources and Normalized Processing}

Due to the lack of data in a few countries along the "Belt and Road", this paper eventually selects 13 countries along the route, including Russia, Mongolia, Malaysia, Jordan, Qatar, Turkey, Saudi Arabia, United Arab Emirates, Egypt, Singapore, Vietnam, Philippines and Iran. Both the dependent variables and the independent variables are annual data, and the time span for the study is 2010-2014. Since the units of measurement vary among indicators, there exists a dimensional problem in the study of the original data. Such a dimensional problem will have a biased effect on the statistical analysis results, reducing the accuracy of the prediction results. In order to avoid the dimensional problem and statistical errors of the original data, this paper normalizes the raw data with the data standardization formula to eliminate the drawback brought by the dimensional difference. The normalization formula and conversion of data sheet are shown in Table 2:

$$
\mathrm{Zij}=(\mathrm{Xij}-\mathrm{Xj}) / \mathrm{OJ}
$$

Table 2. Conversion of data sheet

\begin{tabular}{|c|c|c|}
\hline \multicolumn{2}{|c|}{ Output has been created } & \multirow[b]{2}{*}{$\begin{array}{l}\text { Regarding user-defined missing values as missing } \\
\text { Using all complete data }\end{array}$} \\
\hline $\begin{array}{l}\text { Datasets with missing } \\
\text { values }\end{array}$ & $\begin{array}{c}\text { Definition of missing } \\
\text { The number of cases } \\
\text { used }\end{array}$ & \\
\hline \multicolumn{2}{|c|}{ Grammar } & $\begin{array}{c}\text { DESCRIPTIVES VARIABLES=OFDI IE DIS NGDP } \\
\text { ER IP POP } \\
\text { /SAVE } \\
\text { /STATISTICS=MEAN STDDEV MIN MAX. }\end{array}$ \\
\hline \multirow{7}{*}{$\begin{array}{l}\text { Variables created or } \\
\text { reconstructed }\end{array}$} & ZOFDI & Zscore: OFDI? \\
\hline & ZIE & Zscore: IE? \\
\hline & ZDIS & Zscore: DIS? \\
\hline & ZNGDP & Zscore: NGDP? \\
\hline & ZER & Zscore: ER? \\
\hline & ZIP & Zscore: IP? \\
\hline & ZPOP & Zscore: POP? \\
\hline
\end{tabular}

\subsubsection{Analysis of Correlated Coefficients and Multi-Collinearity Test}

Out of consideration for research rigor, this paper firstly conducts routine tests on the necessity and feasibility of principal component analysis before making a principal component analysis. Two methods are employed in the tests, namely, correlation analysis of index variables, and KMO statistics and Bartlett spherical test. The test results are shown in Table 3:

Table 3. Analysis results of correlated coefficients

\begin{tabular}{|c|c|c|c|c|c|c|c|}
\hline Variables & OFDI & IE & DIS & NGDP & ER & IP & POP \\
\hline OFDI & 1 & -.249 & -.321 & .876 & -.185 & .439 & .489 \\
\hline IE & -.249 & 1 & .274 & -.353 & .112 & -.341 & .526 \\
\hline DIS & -.321 & .274 & 1 & -.070 & -.224 & .019 & .171 \\
\hline NGDP & .876 & -.353 & -.070 & 1 & -.372 & .553 & .442 \\
\hline ER & -.185 & .112 & -.224 & -.372 & 1 & .084 & -.189 \\
\hline IP & .439 & -.341 & .019 & .553 & .084 & 1 & .017 \\
\hline POP & .489 & .526 & .171 & .442 & -.189 & .017 & 1 \\
\hline
\end{tabular}

It can be seen from the correlation analysis that when EO is the dependent variable and the rest are independent variables, the GDP of each country is most correlated with economic openness while exchange rates between RMB and other currencies are less correlated. In addition, the proportion of food in exports and imports as well as geographical distances between China and countries along the Belt and Road are negatively correlated with economic openness. The rest are positively correlated. 
Table 4. KMO statistic and Bartlett spherical test results

\begin{tabular}{|cc|c|}
\hline \multicolumn{2}{|c|}{ Kaiser-Meyer-Olin measure of sampling adequacy, KMO } & .454 \\
& Approximate Chi-square & 369.325 \\
Dartlett spherical test & Degree of freedom & 28 \\
& Significance & .000 \\
\hline
\end{tabular}

Since the geographical distance of each country is constant, and some countries do not release relevant data, the KMO value is slightly less than 0.5 in the KMO and Bartlett tests.

\subsubsection{Principal Component Analysis}

(1) The contribution of variance and the common factor are advanced. Based on the applicability test of the principal component analysis model, this paper employs the SPSS software to analyze the variance contribution of index variables and select the common factors of principal component analysis. The analysis results are shown in Table 5.

Table 5. Variance decomposition and analysis results of extracted principal components

\begin{tabular}{|c|c|c|c|c|c|c|c|c|c|}
\hline \multicolumn{9}{|c|}{ Extraction of principal component } \\
\hline & \multicolumn{9}{|c|}{ Initial eigenvalue } \\
\hline Component & Total & $\begin{array}{c}\text { Variance } \\
\%\end{array}$ & $\begin{array}{c}\text { Accumulation } \\
\%\end{array}$ & Total & $\begin{array}{c}\text { Variance } \\
\%\end{array}$ & $\begin{array}{c}\text { Accumulation } \\
\%\end{array}$ & Total & $\begin{array}{c}\text { Variance } \\
\%\end{array}$ & $\begin{array}{c}\text { Accumulation } \\
\%\end{array}$ \\
\hline 1 & 2.678 & 33.480 & 33.480 & 2.678 & 33.480 & 33.480 & 2.579 & 32.236 & 32.236 \\
\hline 2 & 2.292 & 28.650 & 62.130 & 2.292 & 28.650 & 62.130 & 2.219 & 27.734 & 59.970 \\
\hline 3 & 1.344 & 16.798 & 78.928 & 1.344 & 16.798 & 78.928 & 1.517 & 18.958 & 78.928 \\
\hline 4 & .729 & 9.110 & 88.038 & & & & & & \\
\hline 5 & .662 & 8.281 & 96.319 & & & & & & \\
\hline 6 & .177 & 2.219 & 98.537 & & & & & & \\
\hline 7 & .075 & .935 & 99.472 & & & & & & \\
\hline 8 & .042 & .528 & 100.000 & & & & & & \\
\hline
\end{tabular}

It can be seen from the above table that the first factor has a high eigenvalue and contributes the most to the interpretation of the original variable. The accumulated contribution of the first three factors accounts for $78.9 \%$. Therefore, it is appropriate to extract three factors.

\subsubsection{Regression Analysis}

Since some countries don't have the data which reflects the proportion of food in imports and exports of China and countries along the route, such variables are automatically eliminated in the regression analysis. The relevant regression analysis table is as follows:

Table 6. Model summary

\begin{tabular}{|c|c|c|c|c|c|}
\hline Model & $\mathrm{R}$ & R-squared & Adjusted R-squared & Error of standard estimation & Durbin-Watson \\
\hline 1 & $.658 \mathrm{a}$ & .433 & .424 & 8.4009 & \\
2 & $.776 \mathrm{~b}$ & .603 & .590 & 7.0900 & \\
3 & $.832 \mathrm{c}$ & .692 & .677 & 6.2885 & \\
4 & $.883 \mathrm{~d}$ & .780 & .766 & 5.3596 & \\
5 & $.906 \mathrm{e}$ & .821 & .805 & 4.8841 & \\
6 & $.938 \mathrm{f}$ & .881 & .868 & 4.0159 & \\
7 & $.943 \mathrm{~g}$ & .890 & .877 & 3.8888 & 1.267 \\
8 & $.941 \mathrm{~h}$ & .886 & .874 & 3.9309 & \\
\hline
\end{tabular}

It can be seen from the table that the standard deviation of the estimated value is 3.9309 , and the Debin-Watson test statistic is 1.267 . When the value is approximately equal to $\mathrm{S}$, the residual is independent. 
Table 7. ANOVA ${ }^{\mathrm{a}}$

\begin{tabular}{|c|c|c|c|c|c|}
\hline Model & Sum of squares & Degree of freedom & Mean Square & $\mathrm{F}$ & Significance \\
\hline Regression & 3395.932 & 1 & 3395.932 & 48.118 & $.000 \mathrm{~b}$ \\
\hline Residual & 4446.186 & 63 & 70.574 & & \\
\hline Total & 7842.118 & 64 & & & \\
\hline Regression & 4725.521 & 2 & 2362.760 & 47.004 & $.000 \mathrm{c}$ \\
\hline $2 \quad$ Residual & 3116.597 & 62 & 50.268 & & \\
\hline Total & 7842.118 & 64 & & & \\
\hline Regression & 5429.866 & 3 & 1809.955 & 45.769 & $.000 \mathrm{~d}$ \\
\hline $3 \quad$ Residual & 2412.252 & 61 & 39.545 & & \\
\hline Total & 7842.118 & 64 & & & \\
\hline Regression & 6118.598 & 4 & 1529.650 & 53.251 & $.000 \mathrm{e}$ \\
\hline Residual & 1723.520 & 60 & 28.725 & & \\
\hline Total & 7842.118 & 64 & & & \\
\hline Regression & 6434.703 & 5 & 1286.941 & 53.950 & $.000 \mathrm{f}$ \\
\hline Residual & 1407.415 & 59 & 23.854 & & \\
\hline Total & 7842.118 & 64 & & & \\
\hline Regression & 6906.728 & 6 & 1151.121 & 71.377 & $.000 \mathrm{~g}$ \\
\hline $6 \quad$ Residual & 935.389 & 58 & 16.127 & & \\
\hline Total & 7842.118 & 64 & & & \\
\hline Regression & 6980.104 & 7 & 997.158 & 65.936 & $.000 \mathrm{~h}$ \\
\hline $7 \quad$ Residual & 862.013 & 57 & 15.123 & & \\
\hline Total & 7842.118 & 64 & & & \\
\hline \multirow{3}{*}{$\begin{array}{cc} & \text { Regression } \\
8 & \text { Residual } \\
\text { Total }\end{array}$} & 6945.892 & 6 & 1157.649 & 74.918 & $.000 \mathrm{i}$ \\
\hline & 896.226 & 58 & 15.452 & & \\
\hline & 7842.118 & 64 & & & \\
\hline
\end{tabular}

From the table presented above, it can be seen that the statistical observation value of $\mathrm{F}$ is 74.918 , and the probability $\mathrm{p}$ is 0 , indicating that economic openness has a linear relationship with variables except for those which reflect the proportion of food in imports and exports of China and countries along the route.

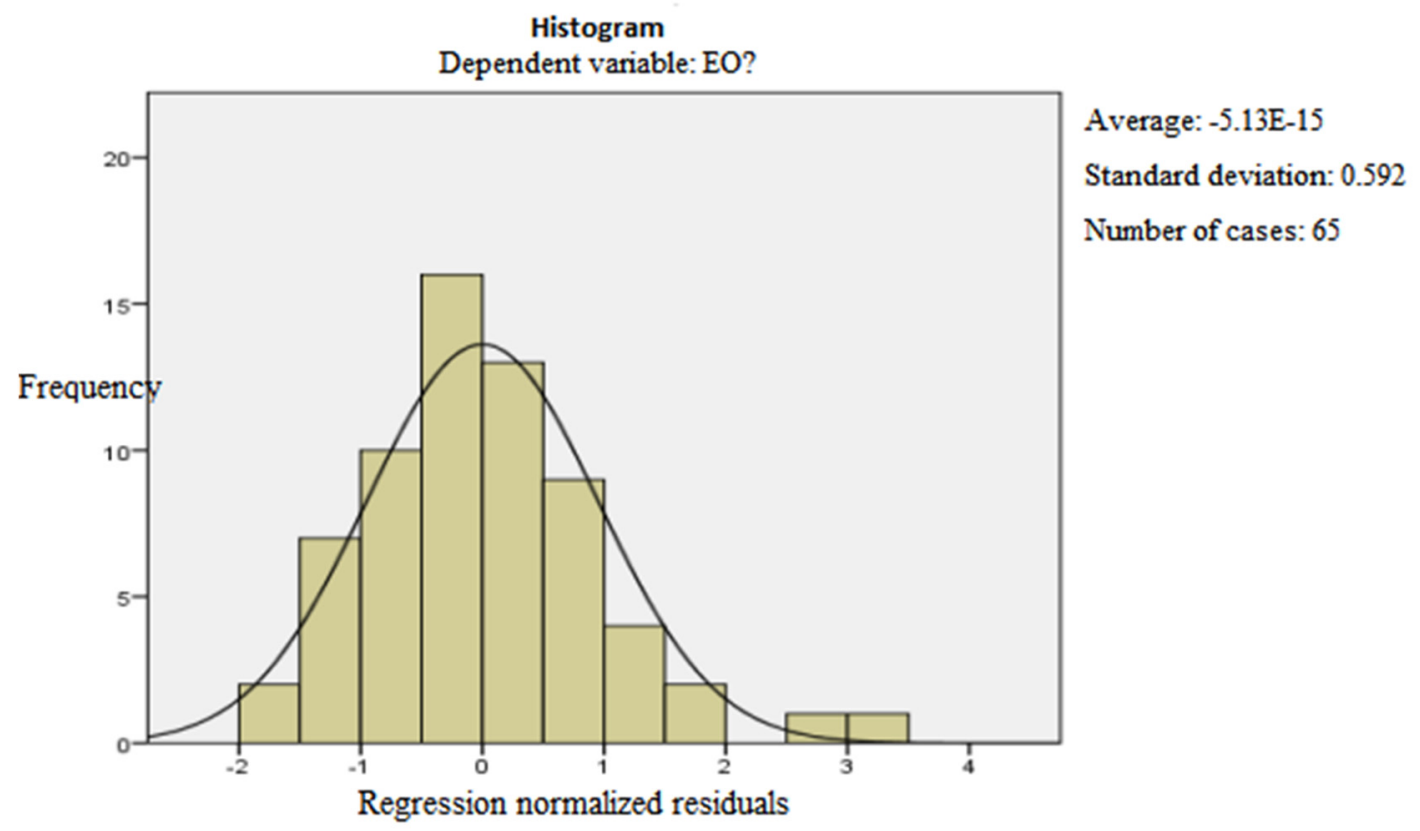

Fig 1. Histogram regression normalized residuals 


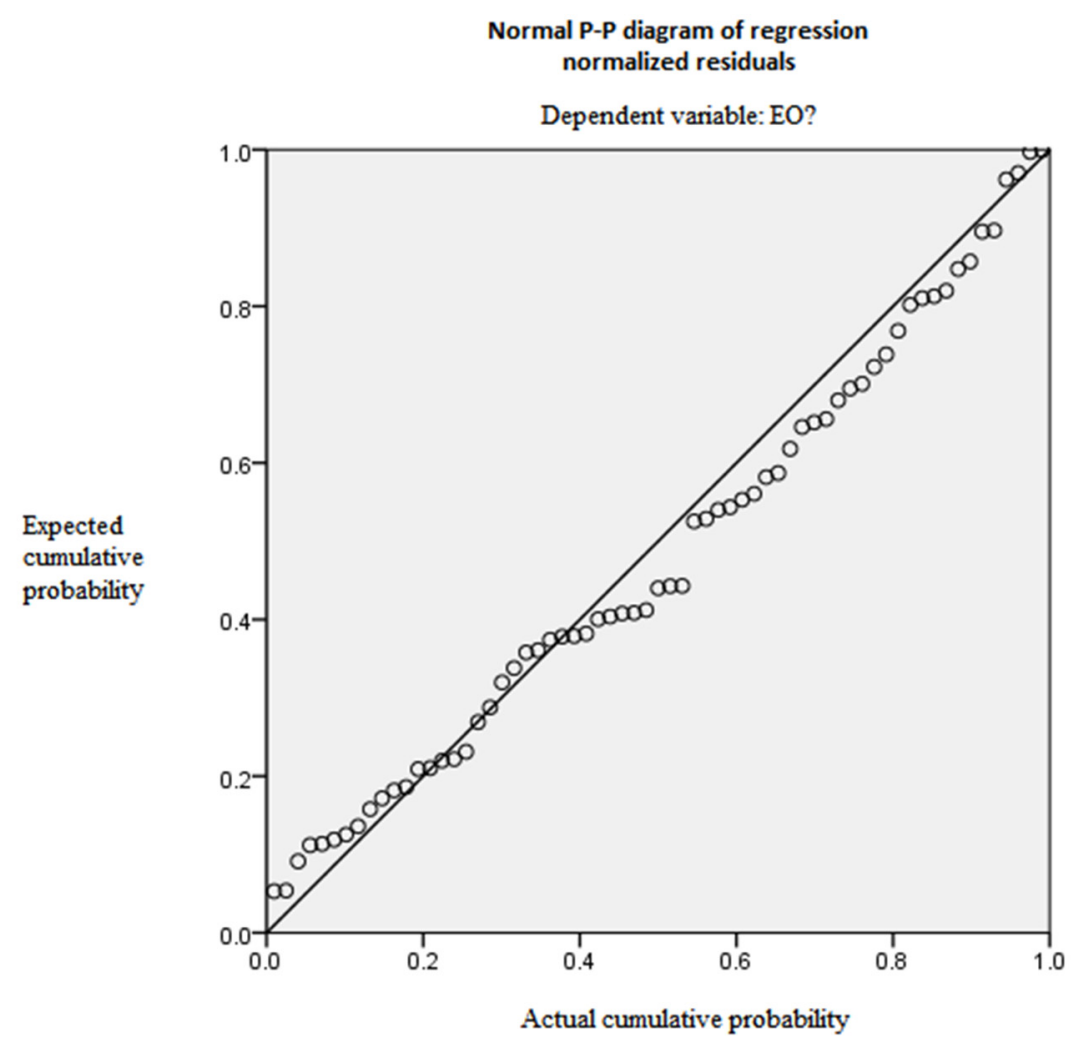

Fig 2. Normal P-P diagram of regression normalized residuals

It can be seen from the histogram of regression normalized residuals that the graph is roughly normal distributed. It can be seen from the normal P-P diagram of the regression that the normalized scatters are close to a straight line, which proves that the normalized residuals are normally distributed.

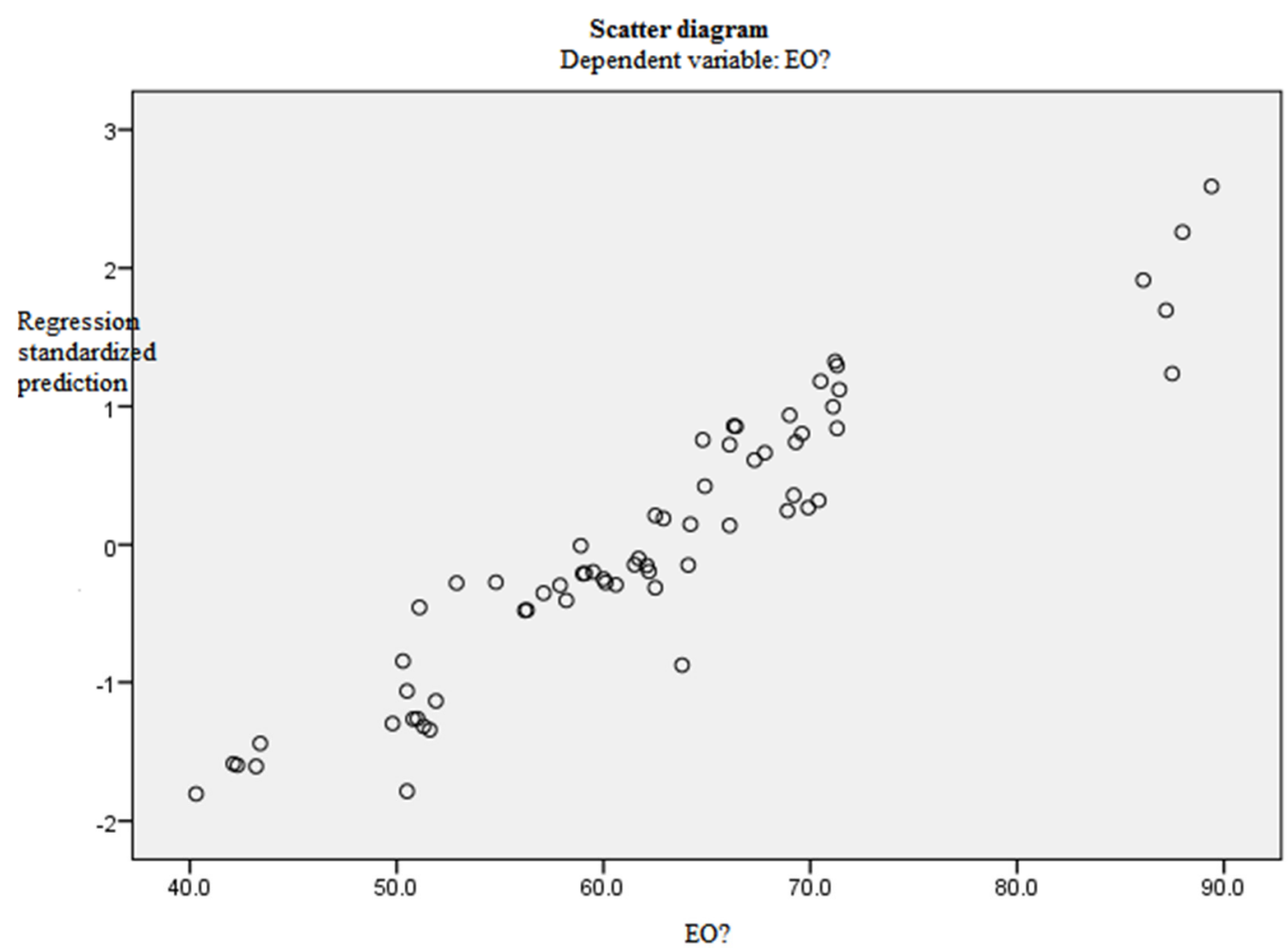

Fig 3. Scatter diagram 
It can be seen from the diagram that economic openness, which is the dependent variable, and regression standardization predictive value are roughly in a straight line.

Table 8. Coefficient

\begin{tabular}{|c|c|c|c|c|c|c|c|}
\hline \multirow{2}{*}{ Model } & \multicolumn{2}{|c|}{ Unstandardized coefficient } & \multirow{2}{*}{$\frac{\text { Standardized coefficient }}{\text { Beta }}$} & \multirow{2}{*}{$\mathrm{t}$} & \multirow{2}{*}{ Significance } & \multicolumn{2}{|c|}{ Collinearity statistics } \\
\hline & $\mathrm{B}$ & Standard error & & & & Tolerance & VIF \\
\hline (Constant) & 71.369 & 1.690 & & 42.235 & .000 & & \\
\hline POP? & $-1.658 \mathrm{E}-7$ & .000 & -.658 & -6.937 & .000 & 1.000 & 1.000 \\
\hline (Constant) & 71.852 & 1.429 & & 50.274 & .000 & & \\
\hline $2 \quad$ POP? & $-1.385 \mathrm{E}-7$ & .000 & -.550 & -6.637 & .000 & .935 & 1.069 \\
\hline ER? & -.001 & .000 & -.426 & -5.143 & .000 & .935 & 1.069 \\
\hline (Constant) & 61.706 & 2.718 & & 22.704 & .000 & & \\
\hline POP? & $-1.102 \mathrm{E}-7$ & .000 & -.438 & -5.603 & .000 & .827 & 1.209 \\
\hline ER? & -.001 & .000 & -.359 & -4.776 & .000 & .893 & 1.119 \\
\hline IP? & .169 & .040 & .333 & 4.220 & .000 & .811 & 1.232 \\
\hline \multirow{2}{*}{$\begin{array}{l}\text { (Constant) } \\
\text { POP? }\end{array}$} & 58.075 & 2.432 & & 23.877 & .000 & & \\
\hline & $-1.451 \mathrm{E}-7$ & .000 & -.576 & -7.965 & .000 & .701 & 1.427 \\
\hline $4 \quad$ ER? & -.001 & .000 & -.361 & -5.643 & .000 & .893 & 1.120 \\
\hline IP? & .202 & .035 & .398 & 5.805 & .000 & .781 & 1.280 \\
\hline IE? & .553 & .113 & .344 & 4.897 & .000 & .742 & 1.349 \\
\hline $\begin{array}{c}\text { (Constant) } \\
\text { POD? }\end{array}$ & 61.354 & 2.392 & & 25.644 & .000 & & \\
\hline POP? & $-1.992 \mathrm{E}-7$ & .000 & -.790 & -8.942 & .000 & .389 & 2.569 \\
\hline ER? & .000 & .000 & -.301 & -4.960 & .000 & .826 & 1.210 \\
\hline IP? & .123 & .039 & .242 & 3.195 & .002 & .531 & 1.882 \\
\hline IE? & .743 & .115 & .462 & 6.438 & .000 & .591 & 1.693 \\
\hline OFDI? & $1.811 \mathrm{E}-6$ & .000 & .303 & 3.640 & .001 & .438 & 2.281 \\
\hline (Constant) & 60.110 & 1.981 & & 30.349 & .000 & & \\
\hline \multirow{2}{*}{$\begin{array}{c}\text { POP? } \\
\text { ER? }\end{array}$} & $-7.712 \mathrm{E}-8$ & .000 & -.306 & -2.654 & .010 & .155 & 6.466 \\
\hline & -.001 & .000 & -.358 & -7.024 & .000 & .791 & 1.265 \\
\hline \multirow{4}{*}{$\begin{array}{c}\text { OFDI? } \\
\text { NGDP? }\end{array}$} & .177 & .033 & .348 & 5.332 & .000 & .483 & 2.069 \\
\hline & .241 & .133 & .150 & 1.815 & .075 & .302 & 3.313 \\
\hline & $3.158 \mathrm{E}-6$ & .000 & .529 & 6.595 & .000 & .320 & 3.127 \\
\hline & -.001 & .000 & -.644 & -5.410 & .000 & .145 & 6.888 \\
\hline \multirow{2}{*}{$\begin{array}{l}\text { (Constant) } \\
\text { POP? }\end{array}$} & 57.738 & 2.153 & & 26.821 & .000 & & \\
\hline & $-5.336 \mathrm{E}-8$ & .000 & -.212 & -2.842 & .006 & .355 & 2.817 \\
\hline ER? & -.001 & .000 & -.317 & -5.768 & .000 & .653 & 1.531 \\
\hline $7 \quad$ IP? & .156 & .035 & .307 & 4.486 & .000 & .421 & 2.375 \\
\hline OFDI? & $3.927 \mathrm{E}-6$ & .000 & .658 & 7.191 & .000 & .236 & 4.244 \\
\hline NGDP? & -.002 & .000 & -.806 & -9.663 & .000 & .283 & 3.531 \\
\hline DIS? & .001 & .000 & .142 & 2.444 & .018 & .582 & 1.719 \\
\hline (Constant) & 58.027 & 2.138 & & 27.137 & .000 & & \\
\hline POP? & $-8.569 \mathrm{E}-8$ & .000 & -.340 & -3.017 & .004 & .152 & 6.590 \\
\hline ER? & .000 & .000 & -.306 & -5.578 & .000 & .642 & 1.559 \\
\hline IP? & .146 & .035 & .287 & 4.152 & .000 & .405 & 2.470 \\
\hline IE? & .196 & .130 & .122 & 1.504 & .138 & .294 & 3.397 \\
\hline OFDI? & $3.798 \mathrm{E}-6$ & .000 & .636 & 6.942 & .000 & .230 & 4.352 \\
\hline NGDP? & -.001 & .000 & -.682 & -5.853 & .000 & .142 & 7.045 \\
\hline DIS? & .001 & .000 & .128 & 2.203 & .032 & .567 & 1.763 \\
\hline
\end{tabular}

a. Dependent variable: EO?

Therefore, the multiple linear regression equation can be derived from the above table: $\mathrm{EO}=-0.340 * \mathrm{POP}-0.306 * \mathrm{ER}+0.287 * \mathrm{IP}+0.122 * \mathrm{IE}+0.636 * \mathrm{OFDI}-0.682 * \mathrm{NGDP}+0.128 * \mathrm{DIS}$ 


\section{Conclusion and Suggestions}

\subsection{Conclusion}

This paper employs the SPSS software to analyze the main factors affecting economic openness. The results show that the degree of economic openness is mainly related to a country's outward foreign direct investment (OFDI) and national gross domestic product (NGDP), followed by the country's total population (POP) and exchange rate (ER). The higher the country's OFDI is, the higher its economic openness is. One the contrary, the higher the country's national gross domestic product (NGDP), total population (POP) and the exchange rate between the country's currency and the US dollar are, the lower its economic openness is.

\subsection{Suggestions}

Based on the conclusions drawn above and the reality of China's economic development, this paper proposes the following suggestions:

\subsubsection{Implement a Comprehensive Opening-Up Strategy}

Due to the gap in economic openness between the eastern and western regions of China, especially the western region where the foreign trade level is far below the national average, there still exists much room for improvement in the future. Therefore, China should strengthen its emphasis on the development of the western region, appropriately adjust the industry structure, and vigorously develop an export-oriented economy [7], thus forming an economic development framework conducive to the enhancement of economic openness.

\subsubsection{Strengthen the Cultivation of Foreign Trade Talents}

To improve economic openness, it is necessary to strengthen business and trade relations with other countries, strengthen exchanges with foreign businessmen, and cultivate more foreign trade talents. With the introduction of the "go global" strategy, an increasing number of enterprises start trying to cooperate with more foreign businesses. Besides, foreign trade talents play a growingly crucial role. Therefore, the state should encourage more young talents to study Business English and foreign trade knowledge, and communicate with foreign businessmen more, thus promoting exchanges with foreign businessmen and improving the country's economic openness.

\subsubsection{Enhance Outward and Inward Foreign Investment}

While developing the domestic economy, China should also attach importance to the role of foreign capital plays in its economic development, because advanced technology and experience from foreign businesses help improve China economic efficiency. Meanwhile, it is necessary to strengthen outward foreign investment of Chinese enterprises. If possible, some companies can work with foreign businesses to establish giant multinationals in which resources can be shared with each other and advantages of both sides can be properly exploited, thus jointly improving China's economic openness.

\section{References}

[1]. Zhang Cabin, The Investment Facilitation of “One Belt One Road” and Choices of China's Foreign Direct Investment-Empirical Analysis Based on Cross-Panel Data and Investment Gravity Model [J]. Journal of International Trade, 2016: 165-176.

[2]. Li Xinyang, On the Diversified Cooperation Mechanism of Maritime Silk Road, World Economics and Politics 2014 (11), 4-17.

[3]. Shen Xianjie \& Xiao Inching, The New Situation of International Regional Economic Cooperation and China's One Belt and One Road Cooperation Strategy, Policing Studies 2015 (5), 93-94. 
[4]. Lu Feng \& Li Xin \& Li Shuangshuang \& Jiang Zhixiao \& Zhang Japing \& Yang Yawed, Why is China? Economic Logics of China's One Belt and One Road Strategy, International Economic Review 2015 (3), 9-34.

[5]. Yang Showmen \& Xing Quean, Measurement of Openness of China's Economy from 1994 to 2011 with GDP Share Calculation Method, Journal of International Trade 2014 (3), 13-24.

[6]. Sun Yang, Research Report on China's Urban and Regional Opening Index in 2015, People.com. Retrieved from http://finance.people.com.cn/n/2015/0628/c1004-27219738.html.

[7]. Cao Hue, Research and Discussion on China's Economic Openness, China Market 2018(1), 1920. 